\section{Corpo e Sexualidade através das imagens em vídeo}

Este estudo teve por objetivo analisar as imagens do corpo vinculadas ao comportamento sexual e reprodutivo nos processos de comunicação mediados pelos chamados vídeos educativos. Buscou-se caracterizar, na relação do sujeito com a tecnologia, os discursos e a direção do olhar que conformam, na atualidade, práticas educativas em saúde. Enfatizando as possibilidades de relações que o vídeo apresenta entre os sujeitos que compõem o texto (enunciador e representado) $e$ profissionais de saúde, por meio dos discursos nas interações com as mensagens, procurou-se identificar questões de natureza social e subjetiva que conformam a base de uma determinada visão do corpo, da sexualidade e das relações de gênero. A partir de três videotecas governamentais e seis não governamentais constituiu-se um banco de Imagens de sessenta títulos. O desenho do estudo teve como sujeitos profissionais de saúde da rede pública do Rio de Janeiro, no período de 1996-1997. A análise, apoiada nos conceitos corpo, sexualidade, identidade social e imagem, voltou-se para a abordagem dos fenômenos educacionais e de comunicação em seus aspectos relacionais, com relevância aos elementos culturais, subjetivos e simbólicos vinculados à clientela/público receptor. Observaram-se concepções de sexualidade generalizantes $e$ de relações de gênero pouco relativizadas quanto ao significado atribuído à experiência sexual e, conseqüentemente, indiferenciação de grupos, culturalmente definidos, na atribuição de significados ao corpo.

Eliane Portes Vargas

Dissertação de Mestrado, 1998

Universidade Federal do Rio de Janeiro/Núcleo de Tecnologia Educacional para a Saúde

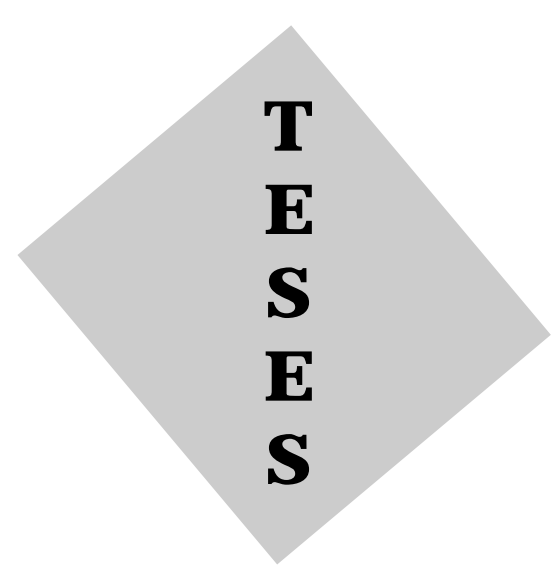

O saber da experiência docente na formação inicial de professores - o estágio na sala 14

A compreensão de que reformulações necessárias no processo de formação inicial de professores exigem atribuição de um papel mais significativo à experiência docente $e$ aos saberes dela oriundos durante esse período gerou a investigação de um estágio supervisionado, conhecido como Sala 14, que priorizava essa experiência. Esse estágio foi realizado durante quinze anos no curso de Pedagogia - Habilitação em Educação Especial - área Deficientes Mentais, na Faculdade de Filosofia e Ciências/Unesp - Campus de Marília.

A análise dos dados obtidos a partir de observações, entrevistas, questionários $e$ análise de documentos permitiu a identificação dos saberes elaborados pelas estagiárias - saber do ser, saber do seu ser e saber ser - e de condições do estágio que favoreceram essa elaboração - ação, reflexão e supervisão, revelando a possibilidade, e não apenas a necessidade, da formação inicial de professores reflexivos a partir da experiência docente refletida e assistida.

Luciana M. Lunardi Campos Tese de Doutorado, 1998 Programa de Pós-Graduação em Educação Faculdade de Filosofia e Ciências Unesp - Marília 